\title{
Proceedings
}

\section{Selection of the Optimal Medium for Adsorption of Plant Proteases ${ }^{\dagger}$}

\author{
Victoria Koroleva ${ }^{1, *}$, Svetlana Olshannikova ${ }^{2}$, Marina Holyavka ${ }^{2}$, Alexander Pashkov ${ }^{1}$ and \\ Valeriy Artyukhov ${ }^{2}$ \\ 1 Department of Biology, Voronezh State Medical University named after N.N. Burdenko, Voronezh Oblast \\ 394036, Russia; vgma-pashkov@yandex.ru (A.P.) \\ 2 Department of Biophysics and Biotechnology, Voronezh State University; Olshannikovas@gmail.com \\ (S.O.); marinaholyavka@yahoo.com (M.H.); artyukhov@bio.vsu.ru (V.A.) \\ * Correspondence: koroleva_victoria@bk.ru \\ + Presented at 1st International Electronic Conference on Catalysis Sciences, 10-30 November 2020; \\ Available online: https://eccs2020.sciforum.net.
}

Published: 10 November 2020

\begin{abstract}
Immobilized enzymes are the most sought preparations on the world market. They are used in medicine, veterinary medicine, food industry, winemaking and brewing. The simplest method for immobilizing biocatalysts on insoluble carriers is the simple adsorption method. Its advantage is to preserve the natural conformation of the enzyme, which slightly reduces its catalytic ability compared to the native form. In our study, we carried out the selection of optimal conditions for adsorption immobilization of acid-soluble chitosan $(\mathrm{Mr}=350 \mathrm{kDa}$ ) enzymes of plant origin (ficin, papain and bromelain) on a matrix. Ficin (EC 3.4.22.3), papain (EC 3.4.22.2), bromelain (EC 3.4.22.4) (Sigma) were chosen as objects of study, azocasein (Sigma) was used as a substrate for hydrolysis, and an acid-soluble high molecular weight chitosan $(350 \mathrm{kDa})$ was used as an immobilization matrix synthesized by Bioprogress CJSC. Suitable buffer systems for immobilization were identified by the optimal ratio of protein content, total and specific activity. Ficin is immobilized on a chitosan matrix using glycine buffer with a $\mathrm{pH}$ of 8.6. Glycine buffer with a $\mathrm{pH}$ of 8.6-10.5 is optimal medium for sorption of papain on chitosan. Bromelain is immobilized on a chitosan matrix under Tris-glycine buffer with $\mathrm{pH} 8.5$ conditions.
\end{abstract}

Keywords: ficin; papain; bromelain; chitosan; immobilization

\section{Introduction}

Immobilized enzymes are the most sought preparations on the world market. They are used in medicine, veterinary medicine, food industry, winemaking and brewing. The simplest method for immobilizing biocatalysts on insoluble carriers is the simple adsorption method. Its advantage is to preserve the natural conformation of the enzyme, which slightly reduces its catalytic ability compared to the native form [1].

Cysteine proteolytic enzymes have particular interest (ficin, bromelain, and papain) due to their broad substrate specificity and the possibility of their use in all industries and production [2].

Chitosan is produced by deacetylation of chitin. It is a straight-chain polymer formed by $\beta$ - $(1,4)$ linked glucosamine monomers; hydroxyl and amino groups are targets for chemical modifications aimed at obtaining suitable materials for various purposes [3,4].

The aim of the work was the selection of optimal conditions for adsorption immobilization of acid-soluble chitosan $(\mathrm{Mr}=350 \mathrm{kDa}$ ) enzymes of plant origin (ficin, papain and bromelain) on a matrix. 


\section{Methods}

Ficin (EC 3.4.22.3), papain (EC 3.4.22.2), bromelain (EC 3.4.22.4) (Sigma) were chosen as objects of study, azocasein (Sigma) was used as a substrate for hydrolysis, and an acid-soluble high molecular weight chitosan $(350 \mathrm{kDa})$ was used as an immobilization matrix synthesized by Bioprogress CJSC.

Immobilization of ficin, papain, and bromelain on a chitosan matrix was carried out by the adsorption method. To $50 \mathrm{mg}$ of chitosan was added $1 \mathrm{~mL}$ of a buffer solution of the enzyme (ficin, papain, bromelain), incubated for $5 \mathrm{~h}$ with periodic stirring. After the end of the incubation, the formed precipitate was washed with $50 \mathrm{mM}$ Tris- $\mathrm{HCl}$ buffer ( $\mathrm{pH}$ 7.5) until there was no protein in the washings (control was carried out on a spectrophotometer at $\lambda=280 \mathrm{~nm}$ ).

Protein content in immobilized enzymes was determined by the Lowry method [5].

\section{Results and Discussion}

During immobilization on a chitosan matrix, the largest amount of ficin is sorbed when using Tris-glycine buffer ( $\mathrm{pH} 8.5$ ), glycine buffer ( $\mathrm{pH}$ 8.6-10.5), borate buffer with the addition of $\mathrm{KCl}$ ( $\mathrm{pH}$ 9.0), bromelain and papain - when using borate buffer with the addition of $\mathrm{KCl}(\mathrm{pH} 8.0-10.0)$, trisglycine buffer ( $\mathrm{pH} 8.5-9.0)$, glycine buffer ( $\mathrm{pH}$ 8.6-10.5) (Figure 1).

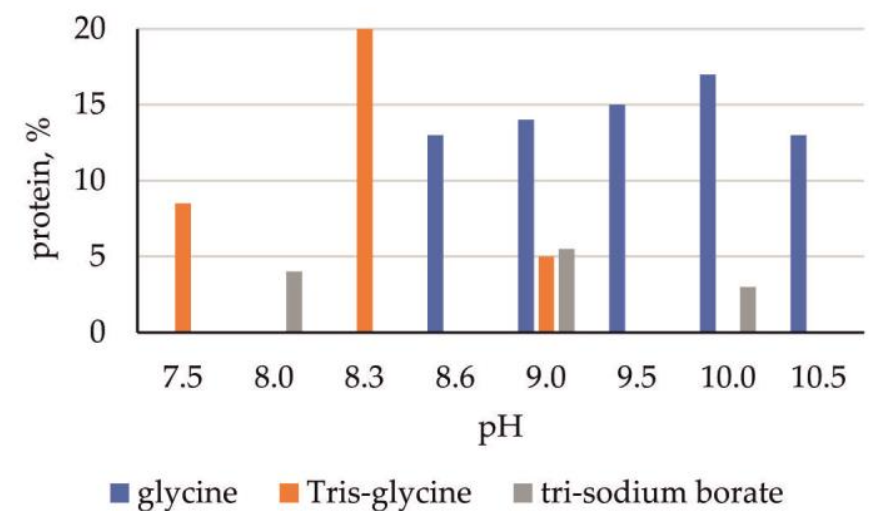

(a)

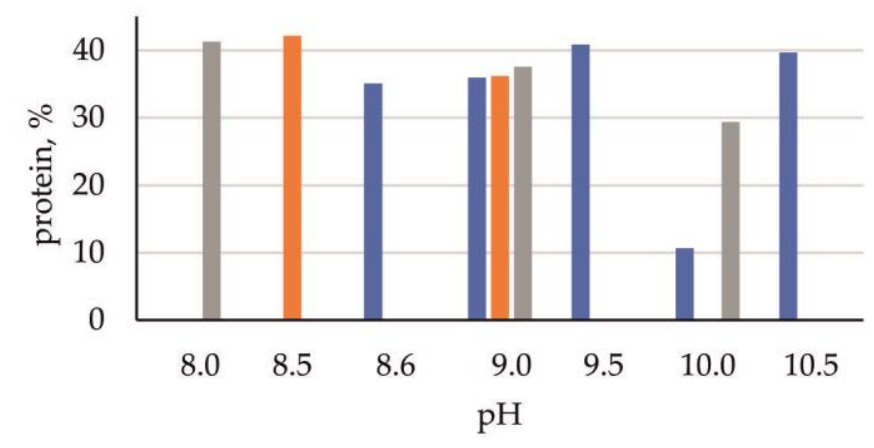

m glycine $\quad$ "Tris-glycine $\quad$ tri-sodium borate

(b) 


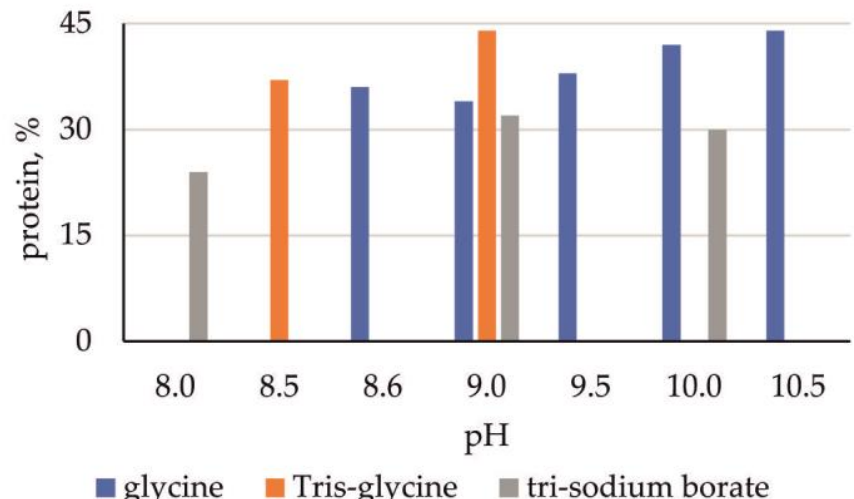

(c)

Figure 1. Protein content in immobilized enzymes (in \% of native biocatalyst): (a) ficin; (b) papain, (c) bromelain.

High total activity was demonstrated by preparations of immobilized ficin using glycine buffer with $\mathrm{pH}$ 8.6, tris-glycine buffer with $\mathrm{pH} 7.5$, 8.5. When immobilized on chitosan, the total activity of papain was found to be higher when using a borate buffer supplemented with $\mathrm{KCl}$ at $\mathrm{pH}$ 8.0-10.0, glycine buffer at $\mathrm{pH}$ 8.6-10.5, and Tris-glycine buffer at $\mathrm{pH}$ 8.5-9.5. Bromelain sorbed on chitosan was the most active under immobilization conditions in tris-glycine buffer with $\mathrm{pH} 8.5$ (Figure 2).

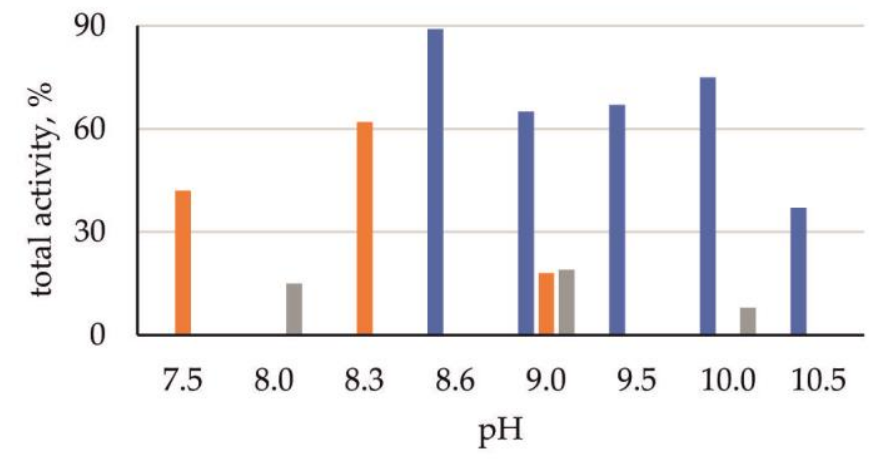

घlycine $\quad$ Tris-glycine $\quad$ tri-sodium borate

(a)

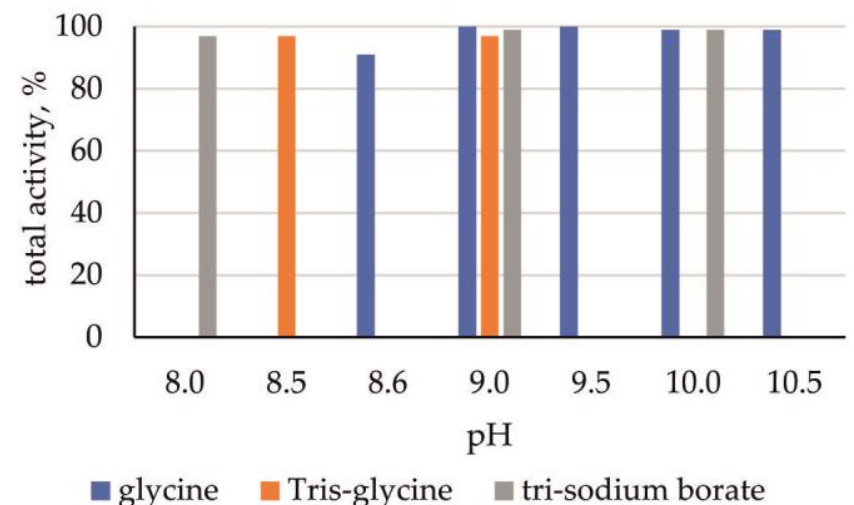

(b) 


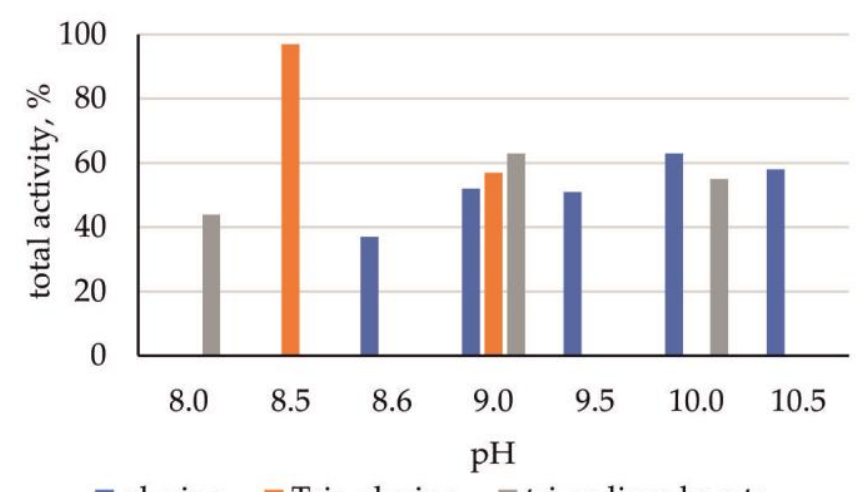

glycine $\quad$ Tris-glycine $\quad$ tri-sodium borate

(c)

Figure 2. Total activity of immobilized enzymes (in \% of native biocatalyst): (a) ficin; (b) papain, (c) bromelain.

The highest specific activity during the immobilization of ficin on chitosan was revealed when using a glycine buffer with $\mathrm{pH}$ 8.6, during the sorption of papain-using glycine with $\mathrm{pH}$ 9.5-10.5, tris-glycine 8.5-9.0, borate with the addition of $\mathrm{KCl}$ with $\mathrm{pH} 9.0$, and adsorption of bromelain - when using tris-glycine buffer with $\mathrm{pH} 8.5$ (Figure 3).

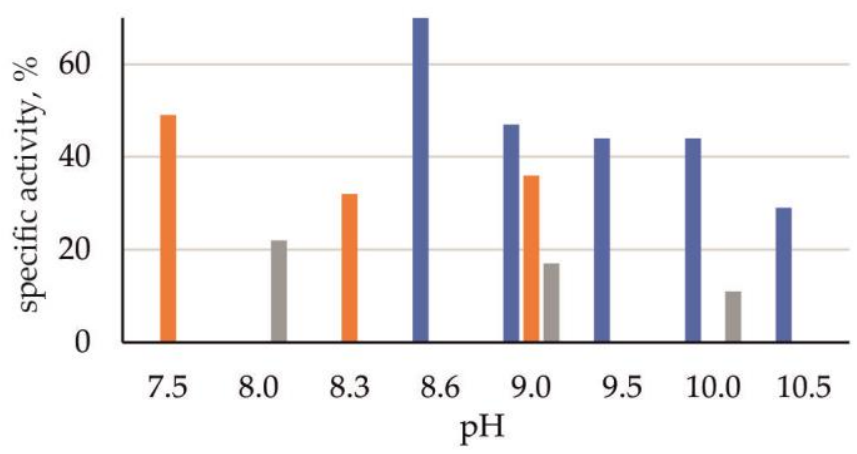

glycine $\quad$ Tris-glycine $\quad$ tri-sodium borate

(a)

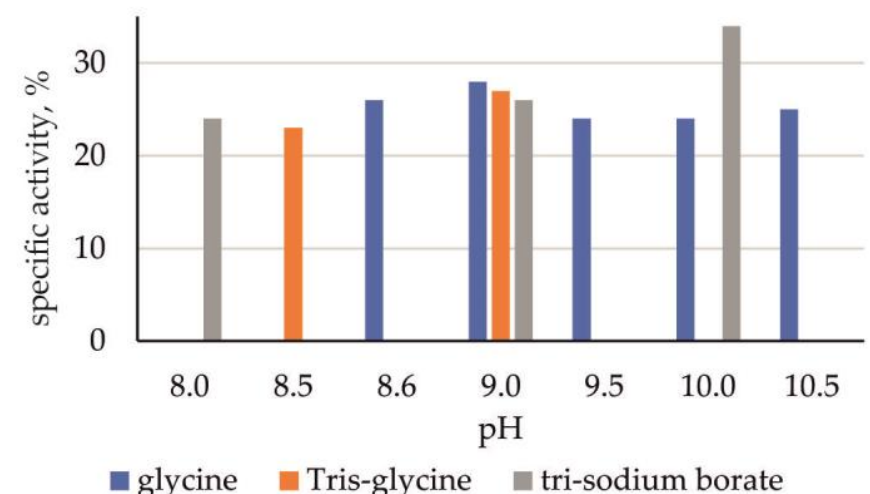

(b) 


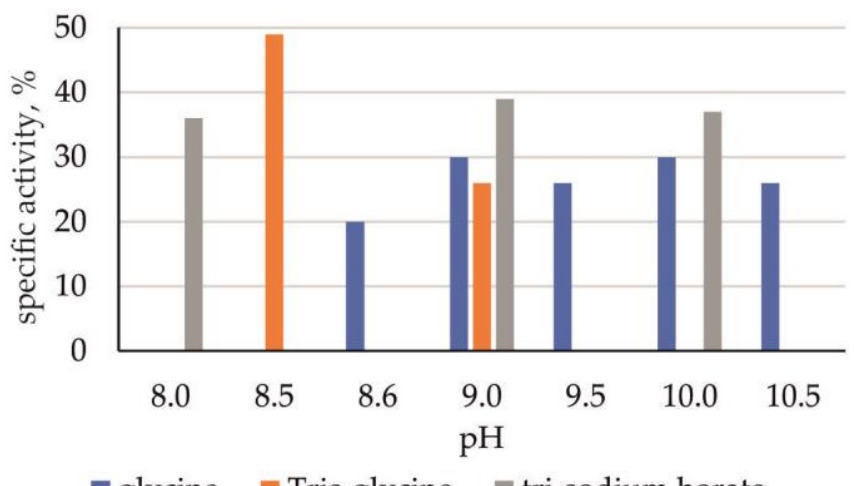

glycine $\quad$ Tris-glycine $\quad$ tri-sodium borate

(c)

Figure 3. Specific activity of immobilized enzymes (in \% of native biocatalyst): (a) ficin; (b) papain, (c) bromelain.

\section{Conclusions}

The optimal buffer systems were selected for the adsorption immobilization of enzymes on the chitosan matrix, namely, glycine buffer $\mathrm{pH} 8.6$ is promising for the sorption of ficin, glycine buffer $\mathrm{pH}$ 8.610.5-for the adsorption of papain, and Tris-glycine buffer $\mathrm{pH} 8.5$ - for the immobilization of bromelain.

\section{Patents}

Holyavka, M., Artyukhov, V., Koroleva, V. Method for obtaining heterogeneous preparation of various dispersities based on bromelain and chitosan. RU 2677232 C2. Date of publication: 16.01.2019 Bull. № 2.

Author Contributions: Authors have equal contributions in the preparation and writing of the article.

Funding: This work was financially supported in the form of a grant from the President of the Russian Federation for state support to young Russian scientists - doctors of sciences (MD-1982.2020.4. Agreement 07515-2020-325).

Conflicts of Interest: The authors declare no conflict of interest. The funders had no role in the design of the study; in the collection, analyses, or interpretation of data; in the writing of the manuscript, or in the decision to publish the results.

\section{References}

1. Feijoo-Siota, L.; Villa, T.G. Native and biotechnologically engineered plant proteases with industrial applications. Food Bioprocess Technol. 2011, 4, 1066-1088.

2. Tavano, O.L.; Berenguer-Murcia, A.; Secundo, F.; Fernandez-Lafuente, R. Biotechnological applications of proteases in food technology. Compr. Rev. Food Sci. Food Saf. 2018, 17, 412-436.

3. Fini, A., Orienti, I. The Role of Chitosan in Drug Delivery. Current and Potential Applications. Am J Drug Deliv 2003, 1, 43-59.

4. Jafarizadeh-Malmiri, H.; Ghaz-Jahanian, M.A.; Berenjian, A. Potential applications of chitosan nanoparticles as novel supports in enzyme immobilization. Am. J. Biochem. Biotechnol. 2012, 8, 203-219.

5. Lowry, O.H.; Rosebrough, N.J.; Faar, A.L.; Randall, R.J. Protein measurement with folin-phenol reagent. J Biol Chem 1951, 193, 265-275.

Publisher's Note: MDPI stays neutral with regard to jurisdictional claims in published maps and institutional affiliations.

(C) 2020 by the authors. Submitted for possible open access publication under the terms and conditions of the Creative Commons Attribution (CC BY) license (http://creativecommons.org/licenses/by/4.0/). 
